\title{
Some Clinicians Speak about Career-long Learning When Life Gets Real
}

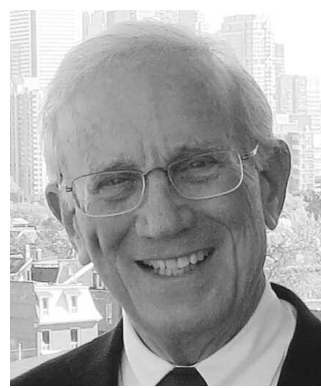

The illiterate of the 21 st century will not be those who cannot read and write, but those who cannot learn, unlearn, and relearn. - Alvin Toffler ${ }^{1}$

In the spring of 2018, a round-Tan ALTan ALtable discussion took place in the presence of 23 rheumatology trainees from the province of Ontario, Canada.

The topic of the discussion was lifelong learning. On the panel were 5 rheumatologists representing different stages of career experience: Dr. A, a recently graduated trainee who is currently in community practice; Dr. B, an experienced community rheumatologist in a small city of Ontario; Dr. C, a senior investigator at the University of Toronto; Dr. D, a mid-career academic rheumatologist/epidemiologist; and Dr. $\mathrm{E}$, a senior community rheumatologist.

The panel was asked to open with statements describing their efforts and strategies to remain abreast of their professional knowledge.

Dr. A noted that because of the volume of knowledge she had studied for recent rheumatology certification examinations, she did not expect that knowledge maintenance was something she would need to be concerned about for some time. However, once in practice, it became apparent that she would need to consider her own continuing education needs because she was no longer in a university setting where she attended mandatory weekly lectures. Dr. A subscribed to an online service that sent her 12 to 15 articles a month in the topic areas that she selected. She also found it useful to periodically discuss complex cases with more experienced colleagues.

Dr. B, a mid-career community rheumatologist, was one of only 2 rheumatologists in a catchment area of over 350,000 people. It quickly became evident that every moment of every day was being consumed by work-related activity. Some definite decisions had to be made, and one was to put a limit on the hours of work and commit to some hours for personal issues and personal life. Dr. B also decided that time could be much more effectively used by hiring people to take care of management, allowing Dr. B to focus on being a physician. Dr. B derives knowledge from speaking to colleagues about cases, attending meetings, and by reading around cases.

Dr. C is a late-career academic rheumatologist and said that she subscribed to about 15 journals, and she named them. Then she admitted that although she had every intention of perusing every one of them, and although she tried to do this upon starting her career, the journals started to accumulate in a pile, and she rarely had time to read them. She found however, that when she was asked to teach, or give a lecture, she was forced to sit down and learn.

Lifelong learning should be adaptable to changes in career, and changes in life.

In times of change, learners inherit the earth; while the learned find themselves beautifully equipped to deal with a world that no longer exists. - Eric Hoffer ${ }^{2}$

Dr. D noted that she was now in the middle of her career. She has reached the parenthood stage of life. Her husband is a busy physician. They have purchased a house for their family, and together they have made a decision to send their children to private schools. Because they are both in busy careers, they have had to hire a nanny. Their income is good. But money is coming in and money is leaving, and they would never have pictured themselves in a situation of such high demand. Dr. D said that she had to make some decisions, and one was that mornings were to be for her family, and so until this phase of life is past, she will not come to work before 9 AM when her children are at school. Similarly, when she comes to work, she has had to learn that she needs time for reading and research. She has had to learn to say no to demands that take away from her ability to perform those activities that she deems most important.

Dr. E was the last to speak. He is a late-career community rheumatologist. He emphasized that when he did his training, he worked in a research clinic. In that clinic, Dr. E learned how to measure. Measuring, he said, told him when he was improving. He participated in many clinical trials while in community practice and he learned from these trials that the essence of excellence was to measure your progress. He felt that he could learn best in practice by reading around his cases, and sometimes this would make him the local expert ${ }^{3}$. He also learned by associating himself with colleagues who were spread across different disciplines. By discussing cases with them, he learned different perspectives and skills.

Personal non-commercial use only. The Journal of Rheumatology Copyright $\odot$ 2019. All rights reserved 
Lifelong learning is a reaction to change.

Change used to come once in a lifetime. Now it comes several times in a lifetime. Change used to be a regional phenomenon; now it is global. Your grandparents as adults witnessed the rise of the automobile. Your parents saw the infusion of radio, then television into their lives. Today's older clinicians have witnessed the pervasiveness of personal computers, then the Internet, then cell phones, then mobile devices into their clinical practices. How do we deal with life-altering change in clinical medicine?

Dr. B was 10 years into a career with gold, chloroquine, and methotrexate as the only tools when biologics came along. Dr. B quickly learned to take on new innovations early and aggressively by reading about them, attending meetings about them, and using them in practice and clinical trials. On the other hand, Dr. C interjected, because her career is academic, she tries her best to teach on topics she knows little about, and this forces her to enter new areas of knowledge. Dr. D also emphasized that teaching was learning, and that opportunities to give rounds or seminars on cutting-edge topics forced her to learn new areas.

Lifelong learning should be intentional, contain specific goals, and result in skills and knowledge that the learner will retain and use for a long time ${ }^{4}$.

Dr. C noted that she could be busy every moment of every day. Since the beginning, her career has been almost frenetic. At a down moment there would be e-mail messages and telephone calls. One day her husband said: "You must learn to take time to do nothing. You must give up your fear of being bored. The CEO of a large company does not work like you. He takes his time and he thinks, then other people run around and put into action whatever new idea he has conceived." Dr. C thought about this, and now when she takes any of her many airplane trips, she does not bring a book. She does not open her computer. She sits, and she does nothing for several hours and becomes bored, and she thinks, and often conceives of new ideas and concepts, enabling her to plan. Lifelong learning should be planned and lead to the acquisition of skills and knowledge that will enhance abilities in an ongoing manner.

\section{Lifelong learning should take advantage of new forms of communication.}

There are different types of media to use for learning today.
These include narrative media such as books, videos, and orators who cannot be questioned; interactive media that is linear, in which the learner controls the sequence through his/her response; adaptive media, in which the learner receives meaningful feedback, either intrinsically from the program or from an observer; communicative media, in which people come together to discuss through text, graphically, or through audiovisual means; and productive media, in which the learner takes his or her acquired skills to create something new or to make his or her own contribution ${ }^{5}$.

Dr. A was the youngest rheumatologist on the panel. She said that she receives her articles online and reads online. Her journals are online, although she still enjoys reading a good book. For her, however, the greatest innovation has been podcasts. She listens to them in her car, and can ingest them without interruption while relaxed and alert and going to work in the morning.

Whatever the strategy, it is apparent that everyone learns differently, and the method of lifelong learning must be individualized. You need to know your own style, but you must also be conscious of the new knowledge gained. Lifelong learning is not about general edification and enlightenment. It is about the acquisition of new knowledge or new skills that are usable, measurable, and long-lasting ${ }^{4}$.

\footnotetext{
ARTHUR A.M. BOOKMAN (D), MD, FRCPC Toronto Western Hospital, University Health Network, Toronto, Ontario, Canada.
}

Address correspondence to Dr. A.A. Bookman, Toronto Western Hospital, University Health Network, 399 Bathurst St., Room 1E424, Toronto, Ontario M5T 2S8, Canada. E-mail: arthur.bookman@uhn.on.ca

\section{REFERENCES}

1. Toffler A. The new educational revolution. In: Future shock. New York: Bantam Books (now Random House); 1970:414.

2. Hoffer E. The true believer: thoughts on the nature of mass movements. New York: Perennial Library; 1989, 1951.

3. Cruess RL, Cruess SR, Boudreau JD, Snell L, Steinert Y. Reframing medical education to support professional identity formation. Acad Med 2014;89:1446-51

4. Knapper CK, Cropley AJ. Lifelong learning in higher education. London; Dover, N.H.: Croom Helm; 2000, 1985.

5. Laurillard D. Rethinking university teaching: a conversational framework for the effective use of learning technologies, 2nd ed. London; New York: Routledge/Falmer; 2002.

J Rheumatol 2019;46:661-2; doi:10.3899/jrheum.180955 